\title{
SPÓR O HISTORIĘ KONTYNENTU I POCHÓD DO POJEDNANIA - ABORYGENI W WIELOKULTUROWEJ AUSTRALII
}

Słowa kluczowe: Aborygeni, wielokulturowość Australii, proces pojednania

\section{WSTĘP}

W niniejszych rozważaniach kluczowym obszarem zainteresowania jest kultura Aborygenów, uważana za najstarszą na świecie. Odrębność poszczególnych społeczności kulturowych, w tym aborygeńskich i nieaborygeńskich ${ }^{2}$ zamieszkujących Australię, wynika przede wszystkim z wartości rdzennych, z którymi utożsamiają się ich członkowie. Dla Aborygenów największe znaczenie ma ich przeszłość, pojmowanie czasu i relacja pomiędzy człowiekiem a naturą, natomiast potomkowie świata angloceltyckiego najbardziej cenią tradycje angloceltyckie, język angielski, świadomość społeczną oraz indywidualizm ${ }^{3}$. Ze spisu powszechnego przeprowadzonego w 2016 roku wynika, że na terenie Australii jest około 650 tysięcy Aborygenów rdzennych mieszkańców Australii, co stanowi 2,8\% populacji tego kontynentu ${ }^{4}$ i potwierdza tym samym, że kultura aborygeńska nie powinna być pomijana podczas debat nad tożsamością ogólnopaństwową.

${ }^{1}$ Mgr; Uniwersytet Jagielloński w Krakowie; ORCID: 0000-0003-0147-4577; e-mail: joanna.chrzanowska@alumni.uj.edu.pl.

${ }^{2}$ Rozumianych jako ludzi o korzeniach nieaborygeńskich.

${ }^{3}$ https://www.creativespirits.info/aboriginalculture/timeline/searchResults?q=\&category=any\&yearFrom=1400\&yearTo=1769 (dostęp 30 XI 2018).

${ }^{4}$ http://www.abs.gov.au/ausstats/abs@.nsf/Lookup/by\%20Subject/2071.0 2016 Main\%20Features Aboriginal\%20and\%20Torres\%20Strait\%20Islander\%20Population\%20Data\%20Summary 10 (dostęp 30 XI 2018); Eugene Stockton w swojej książce 
Głównym celem artykułu jest zwrócenie uwagi na to, jak wiele społeczności aborygeńskich, przede wszystkim tych żyjących poza terenami zurbanizowanymi, wciąż zachowuje dystans do nie-Aborygenów i odczuwa wyobcowanie. Ich sposób postrzegania świata różni się od percepcji rzeczywistości nie-Aborygenów, co jest $w$ dużej mierze związane z zawiłą historią kontynentu australijskiego. Przedstawiony poniżej zarys historyczny w perspektywie aborygeńskiej oraz analiza dwóch kontrowersyjnych świąt państwowych unaocznia, jak wiele pracy przed Aborygenami i nie-Aborygenami, aby można było mówić o jednej, zjednoczonej Australii (The United Australia).

\section{ZARYS HISTORYCZNY W PERSPEKTYWIE ABORYGEŃSKIEJ}

Historia Aborygenów sięga 63 tysięcy lat p.n.e. ${ }^{5}$ To najstarsza kultura na świecie, o której istnieniu Europejczycy nie mieli pojęcia aż do 1606 roku, kiedy to holenderski statek dopłynął do przylądka York i jego załoga po raz pierwszy zetknęła się z miejscową ludnością ${ }^{6}$. Gdy kapitan James Cook dotarł do Australii w 1770 roku, oznajmił, że Australia aż do tamtego momentu była ziemią niczyją, a od 29 kwietnia 1770 całe jej wschodnie wybrzeże oficjalnie należy do Korony Brytyjskiej. Według wielu podręczników szkolnych historia Australii rozpoczęła się właśnie tego dnia. Konflikty pomiędzy Aborygenami a brytyjskimi osadnikami pojawiły się w 1788 roku, kiedy do wybrzeży Australii dopłynęła pierwsza brytyjska flota ze skazańcami. Oszacowano wtedy, że w Australii żyje około 1500 Aborygenów. W rzeczywistości ich populacja była dużo wyższa. Badacze twierdzą, iż liczba autochtonów wynosiła między 750 tysiącami a milionem?.

Dar Aborygenów. Duchowość dla Australijczyków podkreśla, że w Australii żyje co najmniej $90 \%$ przedstawicieli narodów świata, co czyni ją najbardziej wielokulturowym państwem na świecie (E. Stockton, Dar Aborygenów. Duchowość dla Australijczyków, przeł. P. Nowogórski, E. Rekłajtis, Warszawa 2008, s. 11).

${ }^{5}$ https://bth.humanrights.gov.au/significance/historical-context-ancient-history (dostęp 20 XI 2018).

${ }^{6}$ C. Lack, The History and Potential Future of Cape York Peninsula, Brisbane 1839, s. 942.

${ }^{7}$ http://www.abs.gov.au/ausstats/abs@.nsf/Lookup/by\%20Subject/2071.0 2016 Main\%20Features Aboriginal\%20and\%20Torres\%20Strait\%20lslander\%20Population\%20Data\%20Summary 10 (dostęp 30 XI 2018). 
Angloceltyccy przybysze przez wiele lat starali się kontrolować przyrost naturalny rdzennych mieszkańców Australii, co miało ostatecznie doprowadzić do całkowitego wyeliminowania kultury aborygeńskiej. Niejednokrotnie dochodziło do konfliktów zbrojnych, tak zwanych czarnych wojen, oraz aktów ludobójstwa, do których potomkowie „białych Australijczyków", rozumianych jako ludzie o korzeniach angloceltyckich, po dzień dzisiejszy odnoszą się z niechęcią ${ }^{8}$. Wynikiem tych wojen był drastyczny spadek liczby ludności aborygeńskiej. Jak podają źródła, w 1900 roku autochtonów było jedynie 93 200, co stanowi poniżej 1,5\% populacji australijski uchwalał kolejne akty prawne, które nakładały coraz więcej ograniczeń na Aborygenów. Dochodziło do bezprawnych przesiedleń do specjalnych rezerwatów, zakazu przebywania w miastach i niezatrudniania ludzi pochodzenia aborygeńskiego. Powoływanie rad, których głównym zadaniem miała być ochrona spraw Aborygenów, i powstałe w aborygeńskich rezerwatach szkoły, gdzie nauczali niewykwalifikowani nauczyciele, były tylko kolejnym narzędziem kontroli oraz sposobem na odizolowanie autochtonów od reszty społeczeństwa. W 1901 roku rząd oficjalnie przyjął „politykę białej Australii” (White Australia Policy). Federacja przestała uwzględniać rdzennych mieszkańców Australii w spisach powszechnych, a Brytyjska Wspólnota Narodów odstąpiła od decydowania w sprawach „rasy aborygeńskiej”, co oznaczało, że autochtoni podlegali jedynie jurysdykcji poszczególnych stanów australijskich. Co więcej, Aborygeni zostali w krótkim czasie pozbawieni prawa do głosowania i emerytury, do zatrudnienia $w$ wielu miejscach pracy, wstępowania do wojska i urlopu macierzyńskiego, a także prawa do sprawiedliwego procesu. Problem dotknął również dzieci, które były usuwane ze szkół publicznych oraz odbierane rodzicom. Popularny w Australii termin "skradzione pokolenia" (Stolen Generations) odnosi się właśnie do dzieci zabranych rodzicom pochodzenia aborygeńskiego wbrew ich woli w latach 1890-1970. Przez politykę segregacji i społeczne przyzwolenie "biali Australijczycy" nie mieli żadnych kontaktów z ludźmi pochodzenia aborygeńskiego i uważali ich za „rasę wymierającą”. „Sukces” White Australia Policy widoczny jest

${ }^{8}$ H. Reynolds, One History or Two?, [w:] H. Reynolds, Forgotten War, Sydney 2013, s. 230-233.

${ }^{9}$ D. Coyne, Our Population Is Expected to Boom, „Koori Mail” 2016, nr 460, s. 5. 
w liczbach: w latach 40. w siedmiomilionowej populacji 99\% osób należało do rasy białej ${ }^{10}$.

Za koniec tego typu polityki uważa się rok 1965 . Wtedy to została ona zastąpiona polityką integracyjną ${ }^{11}$, mającą na celu dać Aborygenom więcej kontroli nad ich własnym życiem. W rzeczywistości nie było to takie proste, jednak z czasem stawało się coraz bardziej realne, a głos Aborygenów w końcu zaczął być słyszany. Społeczności aborygeńskie zaczęły coraz częściej organizować marsze protestacyjne i uczestniczyć w nich. Australia Południowa była pierwszym stanem, w którym tzw. Akt dyskryminacyjny został zakazany, a tym samym zabroniono dyskryminacji na tle rasowym w miejscach pracy, zamieszkania oraz w miejscach publicznych. W 1967 roku przeprowadzono referendum, w którym ponad $90 \%$ głosujących opowiedziało się za przywróceniem Aborygenom prawa do podlegania sądom Brytyjskiej Wspólnoty Narodów, a tym samym do uwzględniania ich w spisach powszechnych ${ }^{12}$. Pod koniec lat 60 . powołane zostały pierwsze organizacje państwowe, które zajmowały się sprawami Aborygenów, między innymi ich sytuacją polityczną oraz kwestiami związanymi z opieką zdrowotną (zaczęły powstawać ośrodki zdrowia, do których mogli uczęszczać Aborygeni). Jedną z najważniejszych instytucji powołanych $w$ tym czasie było Ministerstwo Spraw Rdzennych Mieszkańców Australii Zjednoczonego Królestwa (The Commonwealth Office of Aboriginal Affairs) ${ }^{13}$. W 1972 roku rząd ogłosił oficjalny koniec „polityki białej Australii”.

Rozpoczęła się wówczas batalia o ziemie bezprawnie odebrane Aborygenom, która trwa do dziś. Komisja ds. Ziem Aborygeńskich (Aboriginal Land Fund Comission) została powołana w 1974 roku, a rok później parlament podpisał Akt rasowej dyskryminacji, w którym rząd przyznał Aborygenom prawo pierwszeństwa do ziem.

Lata 90. to czas powstawania aborygeńskich rad i komisji, których zadaniem była walka o prawa rdzennych mieszkańców i zmuszenie rządu australijskiego do oficjalnego przyznania się do popełnionych na Aborygenach

${ }^{10}$ Aboriginal History, https://www.creativespirits.info/aboriginalculture/history/ aboriginal-history-timeline-1900-1969 (dostęp 12 XII 2018).

${ }^{11}$ https://www.alrc.gov.au/publications/\%20Aboriginal\%20Societies\%3A\%20 The\%20Experience\%20of\%20Contact/changing-policies-towards-aboriginal (dostęp $30 \mathrm{XI}$ 2018).

12 J. Horner, We Learned to Listen, „Koori Mail” 2007, nr 394, s. 27.

${ }^{13}$ Aboriginal History, op. cit. 
zbrodni oraz zadośćuczynienia i pojednania. W życie została wcielona polityka pojednania (Reconciliation Policy) ${ }^{14}$. W 1997 roku został opublikowany raport Bringing Them Home ${ }^{15}$, traktujący o akcie ludobójstwa związanym z okresem skradzionych pokoleń. Australijczycy nie-Aborygeni byli zszokowani szczegółami raportu, ponieważ historia z perspektywy aborygeńskiej była im nieznana.

Początki XXI wieku to ciągłe dyskusje na temat pojednania i niesprawiedliwych wypowiedzi rządu odnośnie do skradzionych pokoleń. W operze w Sydney zorganizowana została konferencja Corroboree 2000, aby zwrócić uwagę na dziesięcioletnią pracę mającą doprowadzić do ostatecznego pojednania z ludnością aborygeńską. Wagę wydarzenia podkreślił pochód o pojednanie następnego dnia (People's Walk for Reconciliation), w którym wzięło udział ponad 300 tysięcy ludzi ${ }^{16}$.

W 2004 roku została powołana Rada Narodowa Rdzennej Ludności (National Indigenous Council) przy australijskim rządzie, a w maju 2005 roku miał miejsce pierwszy oficjalny Dzień Przeprosin (Sorry Day) poza granicami Australii. Dopiero w 2006 roku w stanie Victoria po raz pierwszy oficjalnie uznano i doceniono poświęcenie oraz służbę wojskową rdzennych mieszkańców kontynentu. Kiedy w 2007 roku Organizacja Narodów Zjednoczonych wydała Deklarację praw rdzennej ludności, Australia była jednym z czterech państw spośród 143, które głosowało przeciw ${ }^{17}$. Dopiero rok później, po dwudziestu latach negocjacji, społeczeństwo australijskie wraz z rządem z nowym premierem na czele, Kevinem Ruddem, poparło tę deklarację. W tym samym roku rząd australijski oficjalnie przeprosił ludzi, którzy ucierpieli w związku z problemem skradzionych pokoleń. Zmiany zaszły również w dokumentach urzędowych. Kolejne stany w preambule swoich konstytucji uwzględniały rdzenną ludność ${ }^{18}$. Pojawiły się też pierwsze aborygeńskie paszporty. $\mathrm{W}$ tym samym roku lewicowe partie polityczne

${ }^{14}$ https://www.alrc.gov.au/publications/3.\%20Aboriginal\%20Societies\%3A\%20 The\%20Experience\%20of\%20Contact/changing-policies-towards-aboriginal (30 XI 2018).

${ }^{15} \mathrm{http}$ ://healingfoundation.org.au/app/uploads/2017/04/BTH20-Fact-Sheet-1.pdf (dostęp 30 XI 2018).

${ }^{16}$ R.G. Craven, J. Mooney, Reconciliation: Why We Need to Teach Teacher's to Teach Aboriginal Studies to All Australian Students, Sydney 2006.

${ }^{17}$ https://www.creativespirits.info/aboriginalculture/history/aboriginal-history-timeline-1970-1999 (dostęp 30 XI 2018).

${ }^{18}$ Stan Queensland jako pierwszy uwzględnił w preambule swojej konstytucji ludność rdzenną. 
zjednoczyły się z partią Aborygenów i stworzyły pierwszą federalną Partię Pierwszych Narodów (First Nations Political Party - FNPP). Zmiany widoczne są również $w$ australijskim rządzie federalnym oraz rządach poszczególnych stanów, w których zasiada coraz więcej osób pochodzenia aborygeńskiego, w tym dużo kobiet. Rok 2017 rozpoczął się wybraniem Ken Wyatta na pierwszego federalnego ministra rdzennego pochodzenia ${ }^{19}$. W ostatnich latach społeczeństwa aborygeńskie organizują coraz więcej wydarzeń kulturalno-sportowych, których celem jest nagłośnienie spraw dotyczących Aborygenów i podkreślenie, że proces pojednania wciąż trwa. W sierpniu 2017 radni ze społeczności Yarra w Melbourne jako pierwsi otwarcie zaapelowali o nienazywanie 26 stycznia Dniem Australii. Aż trudno uwierzyć, że uczniowie szkół średnich dopiero w styczniu 2018 roku zaczęli uczyć się o historii aborygeńskiej kultury sprzed 1788 roku, która w końcu została postawiona na równi między innymi z dziejami starożytnej Grecji i Rzymu.

Niestety - mimo uchwalenia wielu aktów prawnych dotyczących spraw aborygeńskich, wciąż powstających instytucji, uczestnictwa Aborygenów w australijskim życiu politycznym oraz ciągłej walki o prawa - wielu rdzennych mieszkańców Australii nadal żyje w bardzo złych warunkach, jest bezrobotnych i ma duży problem z adaptacją do otoczenia. Politycy występują z ogromem różnych propozycji, często przeznaczając pieniądze na sprawy związane z Aborygenami, jednak nie likwiduje to problemów społeczno-socjalnych. Programy rządowe proponują rozwiązania, które być może zadziałały $w$ jednym bądź kilku przypadkach, ale należy pamiętać, że na terenie Australii żyje wiele plemion, w odmiennych warunkach. To, co poprawi sytuację życiową Aborygenów w Nowej Południowej Walii, niekoniecznie sprawdzi się na zdecydowanie mniej zurbanizowanym i rozwiniętym gospodarczo Terytorium Północnym. W efekcie zarówno rząd federalny, jak i rządy poszczególnych stanów inicjują coraz to nowsze programy, co prowadzi do jeszcze większej biurokracji, wiążącej się z wysokimi kosztami administracyjnymi, pochłaniającymi znaczną część środków, które miały trafić do społeczeństw aborygeńskich ${ }^{20}$. W latach 2008-2011 rząd australijski przeznaczył 3,4 miliarda dolarów australijskich na sprawy

\footnotetext{
${ }^{19}$ https://www.creativespirits.info/aboriginalculture/politics/aboriginal-politicians\# toc9 (dostęp 30 XI 2018).

${ }^{20}$ Call for More Accountability, „Koori Mail” 2009, nr 466, s. 11.
} 
Aborygenów ${ }^{21}$. Środki zostały podzielone pomiędzy wiele różnych organizacji, ale niestety nie było osoby bądź instytucji odpowiedzialnej za dopilnowanie rzeczywistej poprawy życia społeczności aborygeńskich. W 2017 roku Narodowe Australijskie Biuro Audytu sporządziło raport recenzujący „Strategię rozwoju i postępu rdzennych społeczności” (Indigenous Advancement Strategy) pt. Zamknqć lukę - raport postępu i priorytetów 2017 (Close the Gap - Progress \& Priorities report 2017) ${ }^{22}$. Wynika z niego, że prawie każdy program lub inicjatywa rządowa skierowane do Aborygenów wciąż dostarczają jedynie z góry narzuconą i powierzchowną pomoc, a przeznaczone fundusze bardzo często rozlokowywane są w niewłaściwy sposób.

\section{DZIEŃ ANZAC I DZIEŃ AUSTRALII - ŚWIĘTA PAŃSTWOWE OCZAMI ABORYGENÓW}

Przez wzgląd na historię, obecną sytuację Aborygenów i wciąż trwający proces pojednania relacje pomiędzy społecznościami aborygeńskimi oraz nieaborygeńskimi nadal wymagają poprawy. Jest ona konieczna we wszystkich sferach życia. Zarys historyczny i polityczny z perspektywy aborygeńskiej pomoże zrozumieć, z czego wynikają różnice w postrzeganiu rzeczywistości przez Aborygenów oraz nie-Aborygenów, rozumianych jako osoby o korzeniach innych niż aborygeńskie. Celem analizy dwóch australijskich świąt państwowych w dalszej części artykułu jest unaocznienie, jak wiele pracy przed Aborygenami i nie-Aborygenami, aby proces pojednania mógł ostatecznie dobiec końca.

Pierwszym świętem państwowym, które wzbudza ogromne kontrowersje, jest niewątpliwie Dzień Anzac. Oficjalne obchody Anzac Day rozpoczynają się Nabożeństwem o świcie (Dawn Service). Tradycja ta ma swoje początki w bitwach pierwszej wojny światowej, podczas której najwięcej ataków przeprowadzono właśnie nad ranem. Dawn Service są organizowane przez australijskie kluby wsparcia weteranów wojennych, tzw. Returned

${ }^{21}$ Budget 2010-11: Indigenous Affairs, Parliament of Australia, http://www.aph. gov.au/About_Parliament/Parliamentary_Departments/Parliamentary_Library/pubs/rp/ BudgetReview201011/IndigenousAffairs (dostęp 12 XII 2018).

22 https://www.humanrights.gov.au/sites/default/files/document/publication/ Close\%20the\%20Gap\%20report\%202017.pdf (dostęp 12 XII 2018). 
and Services League of Australia, przy wsparciu Australijskich Sił Zbrojnych. Święto Anzac zostało zapoczątkowane w celu upamiętnienia Australijczyków oraz Nowozelandczyków poległych podczas pierwszej wojny światowej pod Gallipoli w Turcji, a z biegiem lat stało się symbolem wszystkich, którzy brali udział w pierwszej lub drugiej wojnie światowej. Dopiero po Reconciliation Walk w 2000 roku $^{23}$, który był symbolem chęci pojednania wszystkich Australijczyków - Aborygenów i nie-Aborygenów - zaczęto również dostrzegać rdzennych mieszkańców Australii poległych podczas wojen, zarówno tych za oceanem, jak i domowych. Od tamtej pory część Aborygenów coraz chętniej udziela się publicznie, wyraża swoje zdanie i walczy o prawa rdzennych społeczności Australii. Egzemplifikacją zmagań aborygeńskich organizacji, stowarzyszeń i indywidualnie działających aktywistów ze stereotypami oraz zastanym obrazem Anzac Day jest przedstawiona dalej analiza semiotyczna dwóch ilustracji. Diageza tych materiałów pozwoliła na ich dogłębniejszą interpretację.

Pierwsza rycina przedstawia baner z żołnierzami i kobietami pochodzenia aborygeńskiego na stronie startowej portalu internetowego Narodowej Telewizji Autochtonicznej (National Indigenous Television - NITV) ${ }^{24}$. NITV to australijska stacja telewizyjna dla rdzennych mieszkańców Australii oraz o nich. Przez cały kwiecień i maj 2015 roku owa ilustracja była głównym elementem strony internetowej, aby zakwestionować stereotyp Dnia Anzac: wyłączanie zasług poległych podczas wojen żołnierzy pochodzenia aborygeńskiego, a także milczenie w związku z wojnami domowymi, w których z rąk ",białych Australijczyków” zginęło wielu Aborygenów. NITV pragnie przypomnieć i upamiętnić swoich żołnierzy, ich rodziny, a także całe wspólnoty. Widniejące na ilustracji hasło przewodnie Anzac Day: „Aby nie zapomnieć" (Lest We Forget), w połączeniu ze zdjęciami przedstawiającymi Aborygenów to wizualna synekdocha symbolizująca nie tylko żołnierzy, ale także kobiety, które również zasłużyły się podczas wojen. Aborygeńska stacja telewizyjna chce $w$ ten sposób podkreślić swój wkład w budowanie australijskiej tożsamości i przypomnieć, że pierwszy australijski naród - Aborygeni - stanowi istotną część historii.

${ }^{23}$ Oficjalny marsz przez słynny australijski most Harbour Bridge w Sydney w imię pojednania rdzennych mieszkańców Australii i nie-Aborygenów.

${ }^{24} \mathrm{http}$ ://www.nitv.org.au/fx-program.cfm?pid=E54DB229-D61A-56F8-1924668B8 E6A3409 (dostęp 10 XI 2018). 


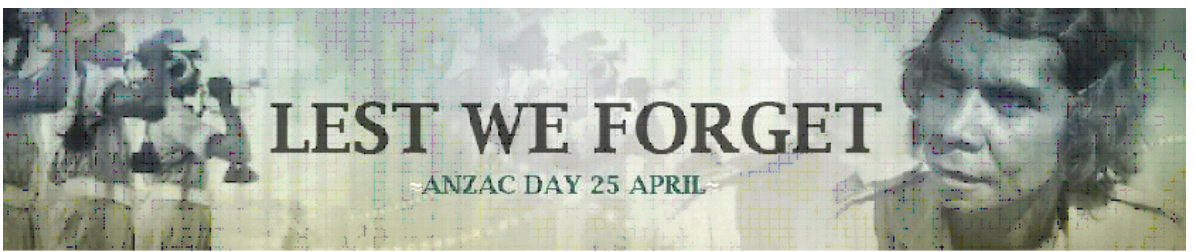

National Indigenous Television, https://www.sbs.com.au/nitv/article/2015/04/06/ nitv-anzac-focus (dostęp 10 XI 2018).

Druga ilustracja to rysunek kanadyjskiego artysty Chrisa Johnstona pt. Aborygeńskie obchody (Aboriginal Commemoration) ${ }^{25}$, który powstał w 2013 roku. Przedstawia on dwa wojenne pomniki pamięci. Jeden upamiętnia wszystkich, którzy pełnili służbę podczas pierwszej i drugiej wojny światowej, a drugi stanowi znak symboliczny odnoszący się do Aborygenów walczących o swoje ziemie oraz godność w trakcie australijskich wojen domowych, przy czym ten ostatni jest przeźroczysty i widać tylko

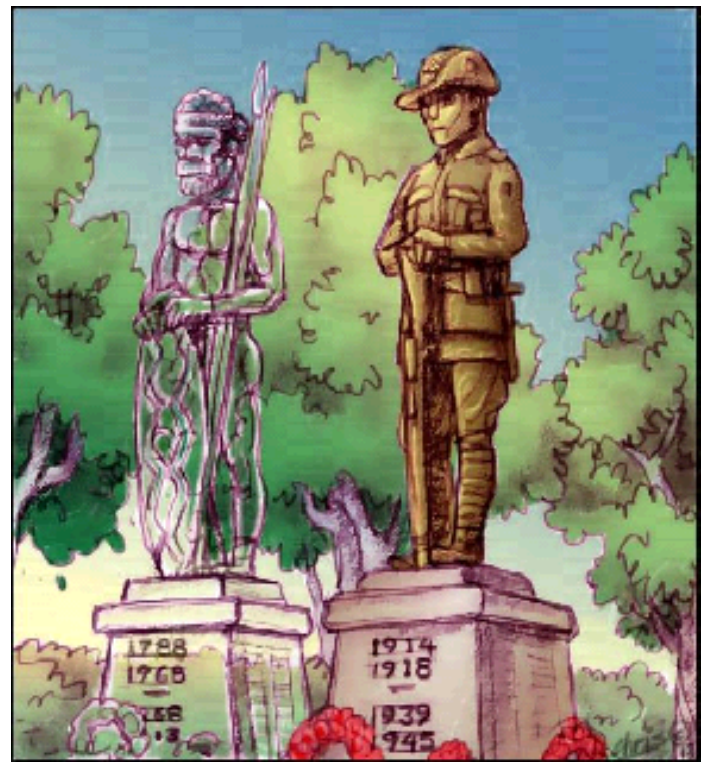

Ch. Johnston, Aboriginal Commemoration, https://www.creativespirits.info/ aboriginalculture/history/aboriginal-anzac-day-war-memorials (dostęp $10 \mathrm{XI}$ 2018).

${ }^{25}$ https://www.creativespirits.info/aboriginalculture/history/aboriginal-anzac-day-war-memorials (dostęp 10 XI 2018). 
jego kontury. Znaczenie konotatywne analizowanej ryciny, które chce przekazać artysta, to zapominanie oraz ignorowanie równie zasłużonych Aborygenów. Różnica polega na tym, że walczyli oni w granicach swojego własnego kraju - o swoją ziemię, przeciwko „białej Australii”, a nie za oceanem. Ironiczny rysunek kwestionuje stereotyp Dnia Anzac, który w znacznej mierze kształtuje powszechną tożsamość "białych Australijczyków”. Artysta w prosty, ale dobitny sposób chce uświadomić nie-Aborygenom i australijskiej władzy, że w Australii brakuje pomników ku pamięci rdzennych mieszkańców, którzy zostali pozbawieni własnych domów i zmuszeni do walki o ziemię, na której żyją od ponad 65 tysięcy lat. Wojny domowe były tak samo krwawe, ważne, a przede wszystkim „australijskie”, jak wszystkie walki zbrojne za oceanem. „Biała historia” nie może wykluczać „Czarnej historii”.

Mimo że obecnie Aborygeni coraz mocniej angażują się w walkę o sprawiedliwość i należytą pamięć oraz szacunek dla swoich najbliższych, a także całych wspólnot, czego wyrazem są między innymi przeanalizowane powyżej ilustracje, to zmiana sytuacji wymaga jeszcze wielu lat ciężkiej pracy. Choć rdzenni mieszkańcy Australii są powoli włączani do obchodów Anzac Day, to historia tego święta wciąż wywołuje wiele kontrowersji. Jak wspomniano, Dzień Anzac początkowo upamiętniał jedynie nie-Aborygenów poległych podczas pierwszej i drugiej wojny światowej. W związku z tym rząd australijski powinien dołożyć wszelkich starań, aby zmienić datę oraz nazwę Anzac Day lub ustanowić nowe święto, które uwzględniałoby każdego, kto kiedykolwiek doświadczył trudów wojen i konfliktów. Niemniej jednak oprócz tych, którzy są przeciwni celebrowaniu tego święta państwowego (co wyrażają poprzez kontestację w różnych formach - protestami, tworzeniem stron internetowych oraz spotów medialnych) lub nie przywiązują do niego wagi, są również tacy, którzy traktują Dzień Anzac jako dzień upamiętnienia członków swoich rodzin lub jako szansę do refleksji o popełnionych w przeszłości błędach; wreszcie i tacy, którzy cieszą się z kolejnego dnia wolnego. Każdy przeżywa to inaczej, ponieważ każdy ma inną historię i inne relacje z nie-Aborygenami, ale jeśli kiedyś ma nadejść ostateczny koniec podziałów na żołnierzy „białych" oraz „aborygeńskich”, to potrzebne będzie wspólne działanie na rzecz sprawiedliwości i uznania.

Kolejnym świętem państwowym wzbudzającym ogromne kontrowersje w Australii jest Dzień Australii. Australia Day, obchodzony 26 stycznia, jest dniem, który ma skłaniać do przemyśleń na temat tego, co znaczy być Australijczykiem. Zalicza się tutaj wszystko, co rozumiane jest jako 
australijskie - ziemię, styl bycia, demokrację, ludzi oraz historię. Wielu obcokrajowców decyduje się właśnie w tym dniu przyjąć obywatelstwo australijskie ${ }^{26}$. Data nawiązuje do dnia, w którym pierwsza brytyjska flota przypłynęła do brzegów Australii ${ }^{27}$. W związku z tym przez wiele lat Święto Australii dotyczyło tylko białej części Australijczyków ${ }^{28}$. Dopiero po wprowadzeniu polityki wielokulturowości w latach 70. zaczęto powoli „uznawać istnienie" Aborygenów oraz czasów przed osadnictwem brytyjskim. 26 stycznia 1988 roku rdzenna ludność Australii po raz pierwszy wyszła na ulice i maszerowała przez Sydney, świętując swoje przetrwanie, podczas gdy nie-Aborygeni obchodzili dwusetną rocznicę swojej imigracji. Aborygeni nazywają ten dzień Dniem Przetrwania bądź Dniem Inwazji, podczas gdy dla potomków angloceltyckich osadników jest to Dzień Australii. Polemika wokół tego święta państwowego sprawia, że coraz więcej ludzi wykazuje zainteresowanie sprawą aborygeńską. Dotyczy to zarówno Aborygenów, nie-Aborygenów, jak i turystów etnicznych, którzy pogłębiają swoją wiedzę i natrafiają na wiele różnych przykładów kontestacji zastanych australijskich stereotypów, w tym tego bezpośrednio związanego z Dniem Australii - stereotypu „białej Australii”. Aby lepiej zobrazować kontrowersje związane z Australia Day, tak jak w przypadku Dnia Anzac dokonałam semiotycznej analizy ryciny - na poziomie semiotyki zarówno denotatywnej, jak i konotatywnej - oraz analizy treści komentarzy nie-Aborygenów, którzy wzięli udział w projekcie „Podziel się uznaniem 26 stycznia”.

Jednym z przykładów kontestacji jest obraz Daniela Boyda o tytule Wyspa skarbów (Treasure Island), który był częścią wystawy „Wojownicy kultury" (Culture Warriors) ${ }^{29}$ w australijskiej Narodowej Galerii Sztuki. Wystawa prezentowała prace trzydziestu artystów o pochodzeniu aborygeńskim z każdego stanu i terytorium. Obraz Boyda przedstawia mapę Australii przed kolonizacją, podzieloną na grupy językowe rdzennych mieszkańców, którzy żyli w zgodzie z naturą, szanując swoje unikalne tradycje oraz rytuały. Owa mapa to replika mapy narysowanej w 1994 roku na zamówienie

\footnotetext{
${ }^{26}$ https://www.australiaday.org.au/about-australia-day/ceremonies/ (dostęp $10 \mathrm{XI}$ 2018).

${ }^{27} 26$ stycznia 1788 do Port Jackson (Sydney) przypłynęła pierwsza brytyjska flota, która składała się z 11 statków z angielskimi skazańcami.

${ }^{28}$ Przede wszystkim w czasach White Australia Policy.

${ }^{29}$ T. Baum, Daniel Boyd. Australian Indigenous Art Triennial Culture Warriors, http://nga.gov.au/Exhibition/NIAT07/Detail.cfm?MnulD=4\&SubMnulD=1\&BioArtistIRN= 33432\&IRN =149628 (dostęp 10 XI 2018).
} 
Australian Institute of Aboriginal and Torres Strait Islander Studies ${ }^{30}$. Słowa „Wyspa skarbów" namalowane na środku to znaki konotatywne metonimiczne odnoszące się do inwazji brytyjskiej, kolonizacji oraz imperializmu. Kolorowe segmenty symbolizują poszczególne klany, którym brutalnie odebrano ziemię, lokalne języki, a także podstawowe prawa człowieka. Przed inwazją brytyjską istniało ponad 500 plemion i jeszcze więcej klanów w ich obrębie, przeszło 250 odmiennych języków, 600 różnych dialektów aborygeńskich. Współcześnie do żywych i używanych języków zalicza się jedynie 60 i jedynie 10\% populacji aborygeńskiej używa w domu jednego z rdzennych języków ${ }^{31}$. Daniel Boyd poprzez prostotę oraz ironię kwestionuje stereotyp „białej Australii”, kiedy to Aborygeni pozostawali niewidzialni. Obraz autochtonów, którzy od czasów przybycia pierwszej floty brytyjskiej w 1788 nieustannie muszą walczyć o sprawiedliwość i równouprawnienie, przypomina o tym, jak ważne jest spojrzenie na Australię z perspektywy jej rdzennych mieszkańców.

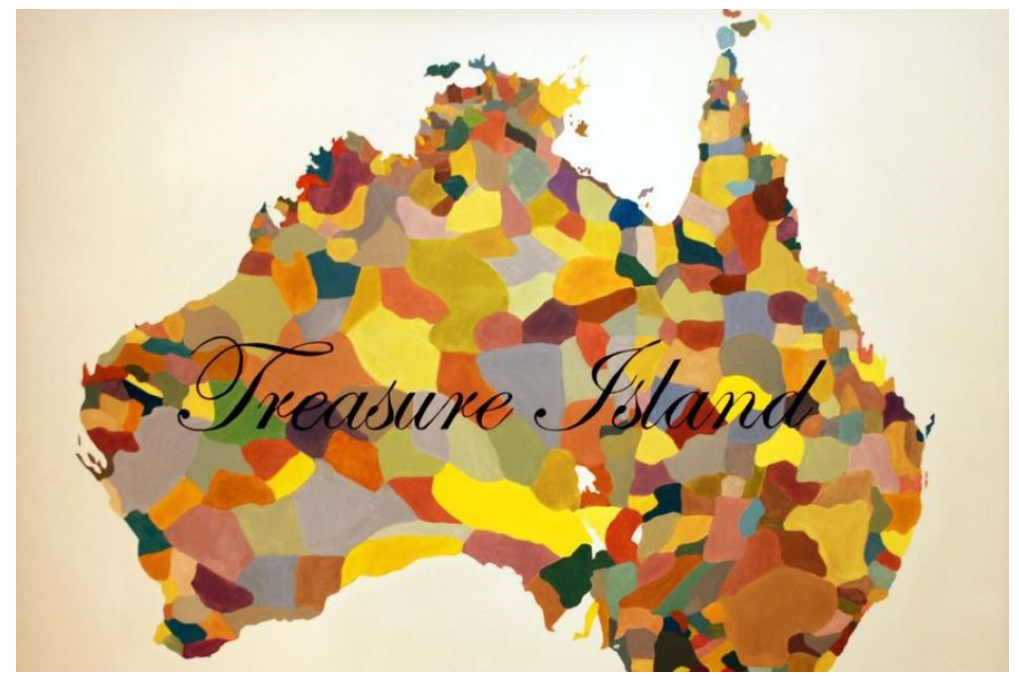

D. Boyd, Treasure Island, http://nga.gov.au/Exhibition/NIAT07/Detail. cfm?MnulD=4\&SubMnulD=1\&BioArtistIRN=33432\&IRN=149628 (dostęp 10 XI 2018).

${ }^{30} \mathrm{https}$ ///aiatsis.gov.au (dostęp 12 XII 2018).

${ }^{31}$ Aboriginal and Torres Strait Islander Population, „Australian Bureau of Statistics", http://www.abs.gov.au/ausstats/abs@.nsf/Lookup/by\%20Subject/2071.0 2016 Main\%20Features Aboriginal\%20and\%20Torres\%20Strait\%20Islander\%20Population\%20Data\%20Summary 10 (dostęp 12 XII 2018). 
Innym jeszcze przykładem kontestacji wartym przywołania ze względu na jego rosnącą popularność (z szansą na osiągnięcie zasięgu międzynarodowego w ciągu kolejnych lat) jest projekt „Podziel się uznaniem 26 stycznia" (Share an Acknowledgment on 26 Jan) ${ }^{32}$. Projekt ten został zainicjowany w 2018 roku i jest skierowany do wszystkich gotowych otwarcie wyrazić swoje wsparcie dla rdzennych mieszkańców Australii. Polega on na wpisywaniu na stronie internetowej krótkich komentarzy przez nie-Aborygenów, którzy chcą okazać szacunek Aborygenom, a także uznać ich za prawowitych właścicieli australijskiej ziemi, np.:

Dziś, 26 stycznia, uznaję, że Aborygeni są prawowitymi strażnikami ziemi, na której żyję. Oddaję hołd przeszłości ich przodków, teraźniejszości i przyszłości oraz przyznaję, że Aborygeni cierpią i płaczą w tym dniu. Przyznaję także, że Aborygeni posiadają silną wolę przetrwania, jako że przetrwali ponad 60 tysięcy lat [Niki Emmett] ${ }^{33}$.

Inicjatywa okazała się świetnym pomysłem. Już podczas pierwszej edycji zebrano prawie 9 tysięcy komentarzy. Celem chrześcijańskiego ruchu Common Grace ${ }^{34}$ jest rozpropagowanie akcji w całej Australii, tak aby dotarła do jak największej liczby osób, a ostatecznie przekonała Australijczyków do publicznego okazywania wsparcia i uznania Aborygenom jako prawowitym właścicielom ziem, na których mieszkają - nie tylko poprzez stronę internetową, ale również $w$ mediach społecznościowych. Ogólnokrajowe inicjatywy tego rodzaju mogą bardzo pozytywnie wpłynąć na relacje Aborygenów z nie-Aborygenami, motywując przy tym rdzennych mieszkańców do dalszej walki, a rząd australijski do zmian.

Dzień Australii jest niewątpliwie świętem niezmiernie kontrowersyjnym i może być interpretowany na wiele różnych sposobów. Aborygenom kojarzy się albo ze smutkiem, stratą, żałobą i inwazją, albo z przetrwaniem - ich kultury oraz wierzeń. Dla nie-Aborygenów może oznaczać natomiast dzień celebracji istnienia Australii, kiedy mogą wyrazić wdzięczność za kraj, który nazywają swoim domem. Są tacy, którzy uważają, że nic nie powinno zostać zmienione i że mają prawo do świętowania początków

32 https://www.commongrace.org.au/jan26_share (dostęp 10 XI 2018).

${ }^{33}$ Pochodzące ode mnie tłumaczenie tekstu dodawanych komentarzy. Oryginalna wersja angielska dostępna jest na stronie internetowej https://www.commongrace.org. au/jan26_share (dostęp 10 XI 2018).

${ }^{34}$ https://www.commongrace.org.au (dostęp 10 XI 2018). 
swojego państwa, ale i tacy, którzy otwarcie mówią o wstydzie, starając się jednocześnie naprawić stosunki pomiędzy Aborygenami oraz nie-Aborygenami, między innymi poprzez przyznanie się do niezmiernie trudnej historii Australii, a także aktywne uczestnictwo w walce o sprawiedliwość dla Aborygenów. Znajdą się wreszcie i tacy, którzy nie przywiązują do święta wagi i w żaden sposób go nie celebrują. Wielość interpretacji tego samego wydarzenia wpływa na jego obraz w oczach turystów etnicznych, którzy w zależności od poziomu zaangażowania w poznawanie innych kultur będą lepiej lub gorzej rozumieć Aborygenów i sposób postrzegania przez nich rzeczywistości oraz kontrowersje związane ze świętami państwowymi określanymi jako Dzień Australii i Dzień Anzac.

\section{ZAKOŃCZENIE}

W wielokulturowej Australii żyją przedstawiciele wielu grup etnicznych oraz narodowych, różniących się między sobą przede wszystkim podstawowymi wartościami, które są uznawane przez dane społeczności za najważniejsze. Próby analizy wartości rdzennych, systemu wierzeń, a przede wszystkim unikalnej duchowości Aborygenów mają na celu uzmysłowienie istoty kultury aborygeńskiej nie tylko turystom etnicznym, ale również Australijczykom bez korzeni aborygeńskich. Przez wzgląd na skomplikowaną historię państwa australijskiego ciężko jest mówić o jednej, niepodzielonej Australii. Próby zrozumienia rzeczywistości w perspektywie aborygeńskiej są niezbędne do poprawy relacji Aborygenów z nie-Aborygenami, w tym przede wszystkim z rządem australijskim.

Według raportu 2016 Australian Reconciliation Barometer zarówno Aborygeni, jak i nie-Aborygeni uważają, że instytucje państwowe mogą zrobić więcej, by zmniejszyć uprzedzenia oraz dyskryminację. 78\% rdzennych mieszkańców Australii i 58\% nie-Aborygenów uczestniczących w badaniu uznało, iż zmiany te powinny zajść w departamentach rządowych (government departments) ${ }^{35}$. Władze Australii bardzo często wycofują przyznane wcześniej środki budżetowe przeznaczone na nowe miejsca pracy oraz mieszkania dla Aborygenów, a także nagminnie odbierają dzieci rodzinom aborygeńskim i oddają je pod opiekę rodzin nieaborygeńskich.

${ }^{35} 2016$ Australian Reconciliation Barometer, https://www.reconciliation.org.au/wp-content/uploads/2017/11/RA_ARB-2016_Overview-brochure_web.pdf (dostęp 12 XII 2018). 
Według raportu Productivity Commission - doradczego organu rządowego - liczba dzieci o pochodzeniu aborygeńskim odbieranych rodzicom wzrosła prawie dwukrotnie od czasów wspomnianych wcześniej oficjalnych przeprosin za Stolen Generations w 2008 roku $^{36}$. W latach 2007-2008 w domach dziecka umieszczono 9070 dzieci rdzennych mieszkańców Australii, a w latach 2016-2017 już 17 664. Co więcej, prawo zakłada, że dzieci mają trafić do rodzin zastępczych o pochodzeniu aborygeńskim. Z raportu wynika jednak, że w latach 2007-2008 do krewnych lub opiekunów o rdzennym pochodzeniu trafiło 74\% dzieci z domów dziecka, a w latach 2016-2017 tylko $67,6 \%{ }^{37}$. System nieustannie karze wspólnoty aborygeńskie, zamiast je wspierać. Pieniądze zamiast być przeznaczane na opracowywanie nowych strategii i planów działania, których celem byłby powrót dzieci do rodzin, wydawane są na umieszczanie ich w domach dziecka. Co więcej, australijski rząd nagłaśnia sprzyjające sobie działania, nierzadko pomijając dobro rdzennych mieszkańców Australii.

Takie sytuacje prowadzą do wyobcowania, braku zaufania ze strony Aborygenów oraz ciągłej kontestacji zastanych stereotypów australijskich. Pozostałości po „białej Australii", w tym rasizm i unikanie rozmów o trudnej przeszłości, wciąż wywołują liczne antagonizmy na tle etnicznym. Czasy wojen domowych oraz krwawych ludobójstw już przeminęły, ale konflikty te są obecne na innej płaszczyźnie. Do nieporozumień i sporów dochodzi przede wszystkim w mediach społecznościowych oraz w różnych sytuacjach życia codziennego. Niemniej jednak z badań przeprowadzonych przez organizację Reconciliation Australia wynika, iż 66\% Aborygenów i 68\% nie-Aborygenów uczestniczących w sondażu wierzy, że w przyszłości będzie można mówić o jednej, zjednoczonej (united) Australii, z czego 44\% Aborygenów oraz $28 \%$ nie-Aborygenów uważa, że zanim dojdzie do całkowitego pojednania, państwo australijskie musi naprawić błędy przeszłości ${ }^{38}$.

${ }^{36} \mathrm{C}$. Wahlquist, Indigenous Children in Care Doubled since Stolen Generations Apology, https://www.theguardian.com/australia-news/2018/jan/25/indigenous-children-in-care-doubled-since-stolen-generations-apology? (dostęp 30 XI 2018).

${ }^{37}$ Report on Child protection services, https://www.pc.gov.au/research/ongoing/ report-on-government-services/2018/community-services/child-protection/rogs-2018-partf-chapter16.pdf (dostęp 30 XI 2018).

${ }^{38} \mathrm{https} / / /$ www.reconciliation.org.au/wp-content/uploads/2017/11/RA_ARB-2016_ Overview-brochure_web.pdf (dostęp 12 XII 2018). 
Obecna sytuacja Aborygenów wpływa również na to, w jaki sposób rdzenni mieszkańcy Australii są odbierani przez turystów etnicznych ${ }^{39}$. Unikanie trudnych tematów, a także niechętne dzielenie się Aborygenów tradycjami, wierzeniami oraz rytuałami sprawiają, że do turystów etnicznych, zarówno zagranicznych, jak i krajowych, docierają tylko powierzchowne informacje na temat społeczności aborygeńskich oraz ich kultur. Aby zrozumieć, skąd bierze się konieczność ciągłej walki o sprawiedliwość, a jednocześnie wyobcowanie z życia publicznego większości rdzennych mieszkańców Australii, należy poznać ich punkt widzenia.

Aborygeński styl życia wynika bezpośrednio z systemu rdzennych wartości. Do poprawy sytuacji Aborygenów niezbędna jest zatem edukacja całego społeczeństwa australijskiego. Dzieje Australii z perspektywy aborygeńskiej powinny być powszechnie znane, gdyż rdzenni mieszkańcy zamieszkują te tereny od ponad 60 tysięcy lat i stanowią istotną część historii tego kraju. Większa świadomość nie-Aborygenów korzystnie wpłynie na turystów etnicznych, którzy potrzebują wiarygodnych źródeł informacji, aby móc poszerzać swoją wiedzę na temat życia, kultury oraz tradycji Aborygenów. Co więcej, edukacja pozytywnie wpłynie na postrzeganie inności nie tylko społeczności aborygeńskich, ale również innych grup etnicznych żyjących w wielokulturowej Australii. Aby sytuacja Aborygenów poprawiła się, niezbędny jest także szacunek oraz równe traktowanie, które mogą być osiągnięte tylko i wyłącznie poprzez podjęcie odpowiednich działań przez rząd australijski.

Na szczęście z raportu 2016 Australian Reconciliation Barometer wynika, że nie-Aborygeni coraz powszechniej akceptują prawdziwą historię Australii oraz niesprawiedliwość, której przez wiele lat doświadczali rdzenni mieszkańcy Australii. Spośród 2277 badanych 64\% przyznaje, że Aborygeni stali się w przeszłości ofiarami wymuszonych przesiedleń i masowych mordów ze strony „białych Australijczyków”, a 57\% uznaje Aborygenów za pierwszych mieszkańców oraz właścicieli ziem australijskich. Co więcej, 67\% zauważa, że do lat 60 . XX wieku autochtoni nie mieli pełnych praw wyborczych, a $68 \%$ potwierdza, iż polityka rządu umożliwiała

${ }^{39}$ Turyści etniczni to turyści, którzy są niekoniecznie emocjonalnie związani w jakikolwiek sposób z odwiedzanym miejscem. Największą wartość stanowi dla nich poznanie nowej kultury i bezpośrednie obcowanie z rdzennymi mieszkańcami. M. Motyka, Turystyka etniczna a turystyka sentymentalna, „Przestrzeń Społeczna” 2016, nr 1, s. 6. 
odbieranie dzieci rdzennym mieszkańcom Australii bez pozwolenia aż do lat 70. XX wieku ${ }^{40}$.

Celem niniejszego artykułu jest unaocznienie nadal istniejącego dystansu pomiędzy nie-Aborygenami i Aborygenami, którzy wciąż pozostają wyalienowani. Szczątkowa wiedza na temat historii, kultury, tradycji oraz systemu podstawowych wartości rdzennych mieszkańców Australii prowadzi do wielu nieporozumień oraz konfliktów, co również wpływa na skomplikowane relacje pomiędzy Aborygenami i nie-Aborygenami. Edukacja oraz przedstawianie perspektywy aborygeńskiej przyczynią się także do poszerzania wiedzy turystów etnicznych, którzy dzięki temu poznają prawdziwą historię Australii i w inny sposób spojrzą na Aborygenów, często odbieranych jako margines społeczeństwa. Omówione święta państwowe obrazują owe różnice w postrzeganiu świata i wciąż żywy konflikt oraz żal społeczności aborygeńskich do „białej Australii”, który nie pozwala na utworzenie jednego, zjednoczonego państwa.

Warto zaznaczyć, że sytuacja ta wydaje się bardziej skomplikowana w przypadku Dnia Australii, ponieważ zarówno Aborygeni, jak i nie-Aborygeni nie czują związku z datą 26 stycznia. Nawet jeśli data ta zostanie zmieniona, to nazwa Australia Day wciąż będzie wzbudzała wiele kontrowersji, jako że kojarzona jest z celebracją założenia pierwszej osady brytyjskiej na terenie Australii, a co za tym idzie - z dyskryminacją i marginalizacją społeczności aborygeńskich w przeszłości. W związku z tym niezbędna jest również zmiana nazwy święta na taką, która nie jest nacechowana negatywnymi emocjami. Działania rządu australijskiego w tym kierunku przyczyniłyby się do poprawy relacji ze społecznościami aborygeńskimi. Projekt Share an Acknowledgment on 26 Jan wydaje się być początkiem zmian, które ostatecznie mogą doprowadzić do ustanowienia nowego święta, uwzględniającego całą Australię i wszystkich jej mieszkańców. Wszystko zależy od popularności projektu, który - dobrze zarządzany - powinien z czasem zyskać zasięg międzynarodowy.

Jeśli chodzi o Anzac Day, zmiana daty oraz nazwy jest również wskazana. Mimo że Aborygeni, który zginęli podczas wojen, zarówno tych za oceanem, jak i tych na terenie Australii, są powoli włączani do obchodów, to święto to wciąż wywołuje wiele kontrowersji. Jest to prawdopodobnie spowodowane historią święta Anzac, które początkowo upamiętniało jedynie

${ }^{40}$ https://www.reconciliation.org.au/wp-content/uploads/2017/11/RA_ARB-2016_ Overview-brochure_web.pdf (dostęp 12 XII 2018). 
nie-Aborygenów poległych podczas pierwszej i drugiej wojny światowej. W związku z tym rząd australijski powinien dołożyć wszelkich starań, aby zmienić jego datę oraz nazwę lub ustanowić nowe święto, które uwzględniałoby każdego, kto kiedykolwiek został dotknięty przez jakiekolwiek wojny, walki lub konflikty na tle etnicznym bądź narodowościowym. Stworzenie projektu na podobieństwo Share an Acknowledgment on 26 Jan mogłoby zapoczątkować zmiany, które pozytywnie wpłynęłyby na relacje Aborygenów i nie-Aborygenów. Dopóki bowiem rdzenni mieszkańcy Australii nie poczują się równie ważni jak nie-Aborygeni, proces pojednania się nie zakończy.

Choć stosunki pomiędzy Aborygenami i nie-Aborygenami nigdy nie będą idealne, mogą one znacząco się poprawić. Wszystko zależy od woli działania obu grup, a także chęci podjęcia dialogu, który mógłby doprowadzić do kompromisu oraz pojednania Aborygenów i nie-Aborygenów. Niemniej jednak jeśli Aborygeni chcą sprawiedliwości oraz poprawy warunków życia, sami muszą się o to postarać. Wszystko zależy od zaangażowania młodego pokolenia rdzennych mieszkańców w sprawy własnych społeczności i pielęgnowanie rodzimej kultury. Mimo iż obecnie istnieje wiele organizacji oraz stowarzyszeń walczących o sprawiedliwość dla Aborygenów, to liczba indywidualnych aktywistów społecznych, którzy mogą zmotywować resztę społeczności do działania, jest niewielka. Jeśli społeczności aborygeńskie nie będą działały wspólnie w imię własnego dobra oraz sprawiedliwości, to ich sytuacja społeczno-ekonomiczna nie ulegnie dostatecznej poprawie, a co za tym idzie - nie zakończy się proces pojednania Aborygenów i nie-Aborygenów.

\section{BIBLIOGRAFIA}

Coyne D., Call for More Accountability, „Koori Mail” 2009, nr 466, s. 11.

Coyne D., Our Population Is Expected to Boom, „Koori Mail” 2009, nr 460, s. 5.

Hoffman B., Turystyka etniczna a doświadczanie kulturowej inności, „Studia Etnologiczne i Antropologiczne" 2009, nr 12, s. 153-166.

Horner J., We Learned to Listen, „Koori Mail” 2007, nr 394, s. 26-27.

Lack C., The History and Potential Future of Cape York Peninsula, „Journal of the Royal Historical Society of Queensland" 1893, nr 6 (4), s. 942-1013.

Motyka M., Turystyka etniczna a turystyka sentymentalna, „Przestrzeń Społeczna” 2016, nr 1, s. $156-177$.

Ratajczak M., Podróż ku wielokulturowości, „Kultura - Historia - Globalizacja” 2015, nr 15, s. 209-220. 
Reynolds H., One History or Two?, [w:] H. Reynolds, Forgotten War, Sydney 2013, s. 228-256. Smolicz J.J., Współkultury Australii, Warszawa 1999.

Stockton E., Dar Aborygenów. Duchowość dla Australijczyków, przeł. P. Nowogórski, E. Rekłajtis, Warszawa 2008.

\section{Netografia}

Craven R.G., Mooney J., Reconciliation: Why We Need to Teach Teacher's to Teach Aboriginal Studies to All Australian Students, https://www.researchgate.net/profile/Rhonda_Craven/publication/264874398_Reconciliation_Why_we_need_to_Teach_Teacher\%27s_to_Teach_ Aboriginal_Studies_to_all_Australian_students_R/links/5403f1d80cf23d9765ā d5a6/ Reconciliation-Why-we-need-to-Teach-Teachers-to-Teach-Aboriginal-Studies-to-all-Australian-students-R.pdf (dostęp 6 III 2019).

http://www.abs.gov.au/ausstats/abs@.nsf/Lookup/by\%20Subject/2071.0 2016 Main\%20 Features Aboriginal\%20and\%20Torres\%20Strait\%20Islander\%20Population\%20Data\%20 Summary 10 (dostęp 30 XI 2018).

https://bth.humanrights.gov.au/significance/historical-context-ancient-history (dostęp $20 \mathrm{XI}$ 2018).

https://www.creativespirits.info/aboriginalculture/timeline/searchResults?q=\&category=any\& yearFrom=1400\&yearTo=1769 (dostęp 30 XI 2018).

https://www.creativespirits.info/aboriginalculture/history/aboriginal-history-timeline-1900-1969 (dostęp 12 XII 2018).

https://www.alrc.gov.au/publications/\%20Aboriginal\%20Societies\%3A\%20The\%20Experience\%20of\%20Contact/changing-policies-towards-aboriginal (dostęp 30 XI 2018).

http://healingfoundation.org.au/app/uploads/2017/04/BTH20-Fact-Sheet-1.pdf (dostęp 30 XI 2018).

https://www.creativespirits.info/aboriginalculture/history/aboriginal-history-timeline-1970-1999 (dostęp 30 XI 2018).

http://www.creativespirits.info/aboriginalculture/politics/aboriginal-politicians\#toc9 (dostęp 30 XI 2018).

http://www.aph.gov.au/About_Parliament/Parliamentary_Departments/Parliamentary_Library/pubs/rp/BudgetReview201011/Indigenous Affairs (dostęp 12 XII 2018).

https://www.pmc.gov.au/sites/default/files/reports/closing-the-gap-2017/sites/default/files/ ctg-report-2017.pdf (dostęp 12 XII 2018).

https://www.sbs.com.au/nitv/article/2015/04/06/nitv-anzac-focus (dostęp 10 XI 2018).

https://www.creativespirits.info/aboriginalculture/history/aboriginal-anzac-day-war-memorials (dostęp 10 XI 2018).

https://www.australiaday.org.au/about-australia-day/ceremonies/ (dostęp 10 XI 2018).

http://nga.gov.au/Exhibition/NIAT07/Detail.cfm?MnuID=4\&SubMnuID=1\&BioArtistIRN= 33432\&IRN=149628 (dostęp 10 XI 2018).

https://aiatsis.gov.au (dostęp 12 XII 2018).

https://www.commongrace.org.au/jan26_share (dostęp 10 XI 2018).

https://www.reconciliation.org.au/wp-content/uploads/2017/11/RA_ARB-2016_Overview-brochure_web.pdf (dostęp 12 XII 2018).

https://www.theguardian.com/australia-news/2018/jan/25/indigenous-children-in-care-doubled-since-stolen-generations-apology? (dostęp 30 XI 2018).

https://www.pc.gov.au/research/ongoing/report-on-government-services/2018/community-services/child-protection/rogs-2018-partf-chapter16.pdf (dostęp 30 XI 2018). 


\title{
THE DISPUTE OVER THE HISTORY OF THE CONTINENT AND THE WAY TO RECONCILIATION - ABORIGINES IN MULTICULTURAL AUSTRALIA
}

\begin{abstract}
The article is dedicated to difficult relations between Australian Aborigines and the Australian mainstream society. Over the centuries these relations were marked with white group's domination and humiliation of the autochthons. The first decades of the $21^{\text {st }}$ century, however, brought significant changes, but still not sufficient enough, in treatment of Australia's first inhabitants. The text reflects on the most important solutions elaborated by both sides: the state and the Aborigines, aiming to improve the situation of disadvantaged minority.
\end{abstract}

Key words: Aborigines, multicultural Australia, process of conciliation 